\title{
Development of English Speaking Skills Through Task-Based Learning Among Primary School Students in Malaysia
}

\author{
Isyaku Hassan \\ Faculty of Languages and Communication, Universiti Sultan Zainal Abidin, Terengganu, Malaysia \\ Izatil Aqmar Mohd Zamzam \\ Faculty of Languages and Communication, Universiti Sultan Zainal Abidin, Terengganu, Malaysia \\ Mohd Nazri Latiff Azmi \\ Faculty of Languages and Communication, Universiti Sultan Zainal Abidin, Terengganu, Malaysia \\ Ahmad Taufik Hidayah Abdullah \\ Faculty of Languages and Communication, Universiti Sultan Zainal Abidin, Terengganu, Malaysia
}

\begin{abstract}
Effective teaching and learning activities are required to provide language learners with chances to develop communicative competence. In 2000, the Malaysian Ministry of Education introduced a program entitled "Literacy and Numeracy Screening" (LINUS) to enhance learners' language proficiency. Despite the existence of this program, research shows that students in Malaysia face difficulties in developing English speaking abilities. This study, therefore, focuses on the application of task-based learning, particularly under the LINUS program. Specifically, the study aims to explore primary school pupils' English speaking achievements and determine the extent of their improvements after learning through the task-based approach. This study employed a quasi-experimental method in which English-speaking tests (pre-test and post-test) were used as data-gathering instruments. The data were collected from a sample of 30 first-year primary school pupils at a national primary school using purposive sampling. The findings showed that as most of the pupils scored higher marks in the post-test compared to the pre-test. Further analysis revealed that task-based learning under the LINUS program enhances pupils' English speaking achievement significantly. The taskbased learning approach provides learners with chances to interact with peers and teachers to develop selfconfidence, which in turn, helps them acquire language skills. It was envisaged that this study could provide English instructors, particularly primary school teachers, with valuable insights into the development of a more creative approach to teaching English speaking subjects through task-based learning under the LINUS program.
\end{abstract}

Index Terms-Malaysia, primary school, pupils, speaking skills, task-based learning

\section{INTRODUCTION}

Speaking proficiency is classified as one of the most fundamental but difficult productive skills among learners of English as a Second Language (ESL) (Abugohar, \& Yunus, 2018; Al-Tamimi, Abdullah, Bin-Hady, 2020; Azlan, Zakaria, \& Yunus, 2019; Mercado, 2017; Bokhari, Md Rashid, \& Chan, 2015; Zaki, Yunus, \& Hashim, 2017). Some major determinants of English speaking proficiency include knowledge of phonology, grammar, and vocabulary (AlTamimi et al., 2020) as well as self-confidence, practices, and exposure to the target language (Azlan et al., 2019). Tuan and Mai (2015) highlighted some speaking problems faced by ESL learners, such as limited topical knowledge, embarrassment, and lack of involvement. The lack of involvement makes learners feel unenthusiastic to acquire the target language effectively. According to Mercado (2017), English learners often face difficulties in expressing their ideas orally as they would not be able to refer to a dictionary or ask their teachers when speaking.

Additionally, the reasons for ESL learners' inability to communicate effectively often include native language influence and inadequate learning time (Sani \& Idris, 2017). At times, ESL learners declare their language anxiety as they struggle to communicate using the target language (Ab Rashid, \& Al-Smadi, 2020). Wen, Ying, \& Azlan, 2018). Likewise, effective teaching and learning activities are required to provide learners with chances to use the target language and develop communicative competence (Pashaie \& Khalaji, 2014; Muhamad, Azmi, \& Hassan, 2020). To develop speaking skills, learners are also required to participate in a non-threatening environment (Pashaie \& Khalaji, 2014). In Malaysian primary schools, English is taught as a second language. The learning of English "is compulsory from pre-school level up to tertiary studies" (Azlan et al., 2019, p. 621). Despite the significance of English in Malaysia (Azmi, Hassan, Ali, Abdullah, Anas, \& Suhaimi, 2020), ESL learners tend to demonstrate low performance in speaking 
ability (Azlan et al., 2019; Bokhari, et al., 2015).

The Malaysian Ministry of Education introduced a new plan to strengthen English language education as stated in the Malaysian Education Blueprint 2013-2025. Language proficiency is one of the six primary elements stated in the Malaysian Education Blueprint which stresses language communication. The ministry decided to give specific considerations to the basic skills of literacy and numeracy to enhance students' language proficiency (Ministry of Education, 2014). As such, a program entitled "Literacy and Numeracy Screening" (LINUS) was introduced. The program aims to ensure that every pupil can attain basic literacy and numeracy skills after attending three years of primary education. The focus of this program includes language skills enhancement, improvement of learning outcomes, special education, curriculum assessment, as well as education for smart students (Hadzir, Alias, Kamaruzaman, \& Yusof, 2016).

Language teaching has focused on changing classroom practices from traditional to more active group learning through the assignment of meaningful tasks, known as task-based learning (Harmer, 2007; Sholeh, 2020). According to Harmer (2007), task-based learning makes the performance of meaningful tasks central to the learning process. In essence, previous studies highlighted the significance of task-based learning in enhancing language proficiency (Mercado, 2017; Mechraoui, Mechraoui, \& Quadri, 2014; Musazay \& Khalid, 2017). Despite its significance, very few studies focused on the effectiveness of task-based learning in developing ESL learners' speaking skills in the Malaysian context (Azlan et al., 2019). Also, to the best of our knowledge, none of the previous local studies focused on the effectiveness of task-based learning in developing English speaking skills among primary school pupils, particularly under the LINUS program. This study, therefore, aims to address the following research questions.

1. What are the pupils' speaking achievements before and after learning through the tasked-based approach under the LINUS program?

2. To what extent have the pupils' speaking skills improve after learning through the tasked-based approach under the LINUS program?

\section{LITERATURE REVIEW}

\section{A. The LINUS Program in Malaysia}

The LINUS program was first introduced in 2010 and expanded in 2014 to incorporate English subjects under the term LINUS 2.0 (Chew, 2018; Ghazali, Omar, \& Saputra, 2021). The program aims to ensure a stable foundation in early literacy skills for pupils in the first, second, and third years of primary education. The pupils are expected to master the basic language skills within three years of primary education (Luyee, Roselan, Anwardeen, \& Mustapa, 2018). Pupils' placement is based on available slots in a school. Nevertheless, pupils with special needs, such as learning difficulties, must go through the LINUS screening in the first and second years and are only identified as students with special needs in the third year. Those who "failed to master all twelve constructs could receive English remedial lesson with differentiated instructions" (Hadzir et al., 2016, p. 43). Besides, teachers who teach LINUS 2.0 subjects are required to be "proficient in English literacy to be more sensitive to the problems faced by LINUS students" (Ghazali et al., 2021, p. 3165).

Additionally, pupils under the LINUS program are required to master 12 constructs concerning English proficiency during screening (Chew, 2018; Ghazali et al., 2021). Although the LINUS program has a positive impact on pupils' English proficiency to some extent, the significance of its effectiveness is still uncertain (Ghazali et al., 2021, p. 3165). Since the implementation of the LINUS program, its success has been deliberated in various studies (e.g. Chew, 2018; Ghazali et al., 2021; Hadzir et al., 2016; Luyee et al., 2018). For instance, Luyee et al. (2018) proved that the LINUS program could improve learning outcomes. According to Chew (2018), students under the LINUS program are taught fascinatingly as teachers tend to use pictures, games, and videos for classroom activities.

On the other hand, Hadzir et al. (2016) revealed that the LINUS program had affected the students' performance both positively and negatively. In this regard, teachers' skills and understanding of the program's objectives have been pointed out as major determinants of the program's success (Sani \& Idris, 2017). For the program to succeed, teachers' deficiencies and difficulties in implementing the LINUS program must be addressed (Chew, 2018). For instance, teachers have to develop effective teaching skills in line with the program's objectives and acquire the necessary competence to regulate students' readiness to perform the learning task. Overall, Chew (2018) predicted that the LINUS program could succeed with the collective efforts of parents, teachers, and relevant authorities.

\section{B. Development of English Speaking Skills through Task-Based Learning}

Research shows that the task-based language learning approach could be effective in developing students' English speaking skills (e.g. Al-Tamimi et al., 2020; Azlan et al., 2019; Hasan, 2014; Nita \& Rozimela, 2019; Omar, Jamaludin, $\&$ Arshad, 2021). For instance, Nita and Rozimela (2019) employed an experimental design to investigate the influence of task-based language instruction on English learners' speaking skills in an Indonesian secondary school. The findings demonstrated that students tend to develop speaking skills significantly through task-based learning. Similarly, Omar et al. (2021) used a quasi-experiment design to examine the effectiveness of the task-based approach in enhancing 
speaking skills among primary school pupils in Singapore. The findings demonstrated that task-based instruction "can be used to teach speaking skills to learners who need exposure to use the language" (p. 49). Sariannur (2017) also revealed that students who were exposed to task-based learning scored higher than students who were exposed to the conventional method.

Recently, some studies found mobile-assisted language learning through the task-based approach to be significantly effective (Annamalai, 2019; Dewi, Ratminingsih, \& Santosa, 2020; Fang, Yeh, Luo, \& Chen, 2021). For instance, Fang et al. (2021) established that mobile-supported task-based and language learning is more effective than the traditional approach on both conversation vocabulary developments. Additionally, research shows that task-based learning develops students' attitudes toward speaking fluency and accuracy in the target language (Murad, 2009; Thanghun, 2012; Leong \& Ahmadi, 2017). According to Mechraoui, Mechraoui, and Quadri (2014), teachers and learners have realized that task-based learning is more effective than traditional learning because the task-based approach promotes learner autonomy. Besides, Erten \& Altay (2009) contended that "task-based activities would result in more meaningful and active participation involving real communication through collaboration with peers" (p. 38). In essence, task-based instruction plays a significant role in developing ESL learners' speaking skills (Musazay \& Khalid, 2017; Nita \& Rozimela, 2019; Omar et al., 2021).

Furthermore, through task-based learning, students are provided with the chance to handle and share conversations in a formal academic setting because the skills and training, which they obtained in the classroom lessons, guide them efficiently (Jassem \& Jassem, 2017). Thus, "when language learners are given time to plan a task before they produce an L2 utterance, they have an opportunity to provide their speech to achieve their communicative goals" (Bakhtiary, Rezvani, \& Namaziandost, 2021, p. 98). Individual learner characteristics such as self-esteem, motivation, and anxiety also define learners' speaking ability. In this regard, Leong and Ahmadi (2017) found that low self-esteem learners with higher anxiety and lack of motivation faced more obstacles in speaking compared to highly motivated learners. Nevertheless, task-based learning could improve learners' self-esteem, motivation, and reduce their speaking anxiety. Thus, providing learners with meaningful tasks using the target language is crucial.

In Malaysia too, a few studies demonstrated the effectiveness of task-based instruction in developing ESL learners' language skills (Ahmed \& Bidin, 2016; Azlan et al., 2019). Specifically, Azlan et al. (2019) employed observation and interviews to ascertain the application of task-based learning activities in developing speaking skills among pre-school children in Malaysia. The study found task-based learning to be effective in developing children's speaking skills. To the best of our knowledge, none of the previous studies focused on the effectiveness of task-based learning in developing English speaking ability with particular consideration of the LINUS program. Therefore, this study focuses on the development of speaking skills among primary school students through the task-based learning approach under the LINUS program in Malaysia. This is because early education is an important stage in language development (Musliman, Ariffin, \& Din, 2013).

\section{THEORETICAL APPROACH}

This study is based on Vygotsky's (1978) social constructivist theory. This theory is chosen because of its essential influence on education (Powell \& Kalina, 2009; Zaki \& Yunus, 2014). Social constructivism presumes that effective learning takes place when it involves communication, participation, and physical activities (Vygotsky, 1978). According to Arsal (2017), the constructivist learning theory involves "student-centered learning approaches such as problem-solving, project-based learning and inquiry-based learning" (p. 2). Therefore, this study applies the constructivist theory in task-based learning to measure the success of task-based activities under the LINUS program. The task-based learning objectives are achieved when students' active involvement in the learning process results in positive learning outcomes (Zaki \& Yunus, 2014). Figure 1 represents the theoretical framework of this study.

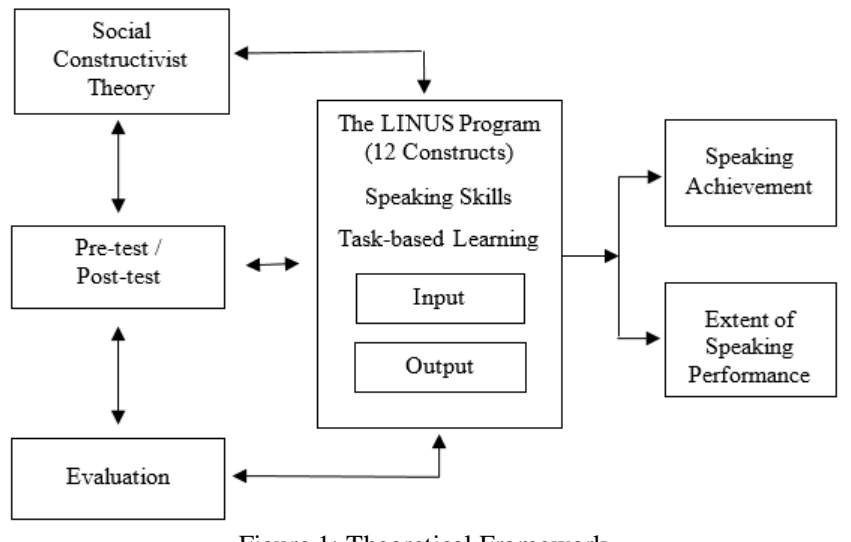

Figure 1: Theoretical Framework

According to Vygotsky (1978), there are two main rules in controlling the learner's cognitive process, namely: More 
Knowledgeable Other (MKO) and Zone of Proximal Development (ZPD). MKO refers to someone who is more conversant than the learners, such as teachers, parents, or more capable peers (Zaki \& Yunus, 2014; Tew, 2015). MKO can also be non-living things, such as electronic tutor that has a higher ability level than the learner (Zaki \& Yunus, 2014). On the other hand, ZPD refers to how the learner narrows the gap between self-achievement and selfimprovement through "problem-solving under adult guidance or in collaboration with more capable peers" (Vygotsky, 1978 , p. 86). In this zone, the learner can complete the given task under the guidance of an adult or teamwork and the learner's capability to find the solutions independently. The basic assumption is that positive learning outcomes can be achieved easily when learners interact with others and perform the learning task successfully. Based on this assumption, the following hypotheses were formulated.

$\mathrm{H}_{1}$ : The pupils' speaking skills improve significantly after learning through the tasked-based approach under the LINUS program.

$\mathrm{H}_{0}$ : The pupils' speaking skills do not improve significantly after learning through the tasked-based approach under the LINUS program.

\section{METHODOLOGY}

This study employed a quantitative approach in which a quasi-experimental method was used to collect and analyze data. The study focuses on students' achievements after learning through the task-based approach under the LINUS program. National School of Demit, a primary school in Kelantan, Malaysia, was chosen as a case study. A case study is an extensive description and analysis of a phenomenon or a social unit bounded by time and place (Stake, 1995; Yin, 2003; Creswell, 2007). The school is purposively selected (Palys, 2008) based on four criteria: convenience, easy access, presence of the LINUS program, and participants' interest. This school is classified as a suburban school with 519 pupils. The study is concerned with investigating a single classroom.

\section{A. Data Collection}

The data were collected from a sample of first-year primary school pupils taught using the LINUS program as stated by the Ministry of Education. English speaking test (pre-test and post-test) was used as a data-gathering instrument. The test was taken from the LINUS program provided for first-year pupils in Malaysia. The tests consist of 12 subjective questions with the tasks of identifying letters, blending phonemes into words, segmenting words into phonemes, pronouncing words, and conversation using appropriate phrases. Constructs 1-4 are more into identifying letters, blending phonemes into words, and segmenting words into phonemes. Construct 5 tests the ability of the participants to understand and use the language at a word level, while construct six is about students' participation in a daily conversation using appropriate phrases. Constructs 7- 12 test students' ability to understand and use the language at phrase level in linear and non-linear texts. This information is presented in Table 1 as follows.

TABLE 1

SPEAKING COMPONENT IN THE LINUS PROGRAM

\begin{tabular}{|l|l|}
\hline SN & Constructs \\
\hline 1 & Ability to identify and distinguish the shapes of the letters of the alphabet \\
\hline 2 & Ability to associate sounds with the letters of the alphabet \\
\hline 3 & Ability to blend phonemes into recognizable words \\
\hline 4 & Ability to segment words into phonemes \\
\hline 5 & Ability to understand and use the language at the word level \\
\hline 6 & Ability to participate in daily conversations using appropriate phrases \\
\hline 7 & Ability to understand and use the language at phrase level in linear texts \\
\hline 8 & Ability to understand and use the language at phrase level in non-linear texts \\
\hline 9 & Ability to read and understand sentences with guidance \\
\hline 10 & Ability to understand and use the language at sentence level in non-linear texts \\
\hline 11 & Ability to understand and use the language at sentence level in linear texts \\
\hline 12 & Ability to construct sentences with guidance \\
\hline
\end{tabular}

The LINUS test has three main objectives of which the first one is relevant to this study: 1) learners should be able to communicate with peers and adults properly; 2) read and comprehend simple texts and stories; 3) write a range of texts through a variety of media. These objectives consist of four skills: listening, speaking, reading, and writing. Nevertheless, this study considers speaking tests as it focuses on speaking abilities. Each respondent was given 30 minutes to complete the pre-test and the post-test respectively. After taking the pre-test, the pupils were taught for four months using the task-based learning approach. The task-based learning on speaking activities was taught three times a week by the researchers. Subsequently, the post-test was administered to the pupils. The results were recorded in the standard LINUS forms provided by the Ministry of Education.

\section{B. Data Analysis}

The data were analyzed using descriptive statistics and Pearson Correlation as employed in previous studies. Descriptive statistics were used to examine the participants' achievements before and after the task-based learning activities. On the other hand, the Pearson Correlation analysis was used to ascertain the extent to which the respondents' 
performance improves after learning through task-based learning activities. All inferences were set at an alpha ( $\alpha$ ) level of $\leq 0.05$ using the SPSS software (SPSS Inc., Chicago, IL, USA, 20.0).

\section{FINDINGS}

This study aims to achieve two main objectives; first, to measure the pupils' speaking achievements before and after learning through the task-based approach; second, to determine the extent to which the pupils' speaking performance improves after learning through the task-based approach. The analysis was performed based on the pre-test and post-test results. The participants' demographic information shows that 18 of the pupils, amounting to $60 \%$, are females, while $40 \%$ of them are males. Since this study examines a single class of first-year pupils, all respondents are seven years old. The pupils' achievements in the pre-test and post-test are shown in Table 2 as follows.

TABLE 2

PRE-TEST AND POST-TEST SCORES

\begin{tabular}{|c|c|c|c|c|c|c|c|c|}
\hline \multirow[b]{2}{*}{ Variables } & \multicolumn{4}{|c|}{ Pre-test Marks } & \multicolumn{4}{|c|}{ Post-test Marks } \\
\hline & $\begin{array}{l}0-25 \\
(\mathrm{FP})\end{array}$ & $\begin{array}{l}26-50 \\
\text { (FP) }\end{array}$ & $\begin{array}{l}51-75 \\
\text { (FP) }\end{array}$ & $\begin{array}{c}76-100 \\
\text { (FP) }\end{array}$ & $\begin{array}{l}0-25 \\
\text { (FP) }\end{array}$ & $\begin{array}{c}26-50 \\
(\mathrm{FP})\end{array}$ & $\begin{array}{l}51-75 \\
(\mathrm{FP})\end{array}$ & $\begin{array}{c}76-100 \\
\text { (FP) }\end{array}$ \\
\hline Construct 1 & $0(0)$ & $4(13.3)$ & $17(56.7)$ & $9(30.0)$ & $0(0)$ & $0(0)$ & $0(0)$ & $30(100.0)$ \\
\hline Construct 2 & $2(6.7)$ & $6(20.0)$ & $16(53.3)$ & $6(20.0)$ & $0(0)$ & $0(0)$ & $6(20.0)$ & $24(80.0)$ \\
\hline Construct 3 & $9(30.0)$ & $14(46.7)$ & $7(23.3)$ & $0(0)$ & $0(0)$ & $2(6.7)$ & $28(93.3)$ & $0(0)$ \\
\hline Construct 4 & $12(40.0)$ & 11(36.7) & $7(23.3)$ & $0(0)$ & $0(0)$ & $2(6.7)$ & $28(93.3)$ & $0(0)$ \\
\hline Construct 5 & $14(46.7)$ & $7(23.3)$ & $9(3.0)$ & $0(0)$ & $0(0)$ & $3(10.0)$ & $27(90.0)$ & $0(0)$ \\
\hline Construct 6 & $14(46.7)$ & $11(36.7)$ & $5(16.7)$ & $0(0)$ & $0(0)$ & $3(10.0)$ & $27(90.0)$ & $0(0)$ \\
\hline Construct 7 & $2(6.7)$ & $16(53.3)$ & $8(26.7)$ & $4(13.3)$ & $0(0)$ & $0(0)$ & $8(26.7)$ & $22(73.3)$ \\
\hline Construct 8 & $19(63.3)$ & $6(20.0)$ & $5(16.7)$ & $0(0)$ & $0(0)$ & $5(16.7)$ & $25(83.3)$ & $0(0)$ \\
\hline Construct 9 & $12(40.0)$ & $13(43.3)$ & $5(16.7)$ & $0(0)$ & $0(0)$ & $7(23.3)$ & $23(76.3)$ & $0(0)$ \\
\hline Construct 10 & $4(13.3)$ & $15(50.0)$ & $7(23.3)$ & $4(13.3)$ & $0(0)$ & $0(0)$ & $14(46.7)$ & $16(53.3)$ \\
\hline Construct 11 & $19(63.3)$ & $6(20.0)$ & $5(16.7)$ & $0(0)$ & $0(0)$ & $16(53.3)$ & $14(46.7)$ & $0(0)$ \\
\hline Construct 12 & $15(50.0)$ & $4(13.3)$ & $11(36.7)$ & $0(0)$ & $0(0)$ & $12(40.0)$ & $18(60.0)$ & $0(0)$ \\
\hline Total (\%) & 33.9 & 31.3 & 28.3 & 6.4 & $0(0)$ & 13.9 & 60.5 & 25.6 \\
\hline
\end{tabular}

Table 2 shows the pupils' performance before and after and after taking the tests based on the 12 constructs in the LINUS program. Overall, 33.9\% of the pupils scored between 0-25 marks in the pre-test, 31.3\% scored 26-50 marks, $28.3 \%$ scored 51-75 marks, while only 6.4\% scored between 76-100 marks. In the post-test, none of the pupils scored between 0-25 marks, $13.9 \%$ scored 26-50 marks, 60.5\% scored 51-75 marks, whereas 25.6\% scored 76-100 marks. These marks indicate some improvements as most of the pupils scored higher marks in the post-test compared to the pre-test. The first objective of this study was to measure the respondents' speaking achievements before and after learning through the task-based approach. This information is presented in the following table.

TABLE 3

PUPILS' ACHIEVEMENT THOUGH TASK-BASED LEARNING

\begin{tabular}{|c|c|c|c|c|c|c|}
\hline \multirow{2}{*}{ SN } & \multirow{2}{*}{ Constructs } & No. & \multicolumn{2}{|c|}{ Pre-test } & \multicolumn{2}{c|}{ Post-test } \\
\cline { 3 - 6 } & & & Mean & St. Dev. & Mean & St. Dev. \\
\hline 1 & Construct 1 & 30 & 3.17 & .648 & 4.00 & .000 \\
\hline 2 & Construct 2 & 30 & 2.87 & .819 & 3.80 & .407 \\
\hline 3 & Construct 3 & 30 & 1.93 & .741 & 2.93 & .254 \\
\hline 4 & Construct 4 & 30 & 1.83 & .791 & 2.93 & .254 \\
\hline 5 & Construct 5 & 30 & 1.83 & .874 & 2.90 & .305 \\
\hline 6 & Construct 6 & 30 & 1.70 & .751 & 2.90 & .305 \\
\hline 7 & Construct 7 & 30 & 2.47 & .819 & 3.73 & .451 \\
\hline 8 & Construct 8 & 30 & 1.53 & .776 & 2.83 & .379 \\
\hline 9 & Construct 9 & 30 & 1.77 & .728 & 2.77 & .430 \\
\hline 10 & Construct 10 & 30 & 2.37 & .889 & 3.53 & .507 \\
\hline 11 & Construct 11 & 30 & 1.53 & .776 & 2.47 & .507 \\
\hline 12 & Construct 12 & 30 & 1.87 & .937 & 2.60 & .498 \\
\hline & Total & 30 & 2.07 & .935 & 3.12 & .618 \\
\hline
\end{tabular}

Performance level: 0.1-2.99=low, 3.0-3.49= moderate, $3.5-5=$ high

Table 3 demonstrates that in all 12 constructs, the pupils performed better during the post-test $(\mathrm{Mean}=2.07$, $\mathrm{SD}=0.935$ ) compared with the pre-test (Mean=3.12, $\mathrm{SD}=0.618$ ). These findings indicate that the pupils' speaking performance was low (Level=0.1-2.99) during the pre-test. Overall, the pupils' achievement improved from low performance (Level=0.1-2.99) to moderate performance (Level=3.0-3.49) after learning through the task-based approach. These findings imply that four-month task-based activities under the LINUS program can improve pupils' speaking abilities. The second research question aims to ascertain the extent to which the pupils' English speaking skills improved after learning through the task-based approach. This evidence is represented in the following table. The following table shows the extent of the pupils' improvement in speaking abilities after the task-based learning. 
TABLE 4

PUPILS' EXTENT OF IMPROVEMENT IN SPEAKING ABILITY

\begin{tabular}{|c|c|c|c|c|}
\hline Tests & Mean & St. Deviation & Correlation & Sig. \\
\hline Pre-test & 2.07 & .935 & .636 & .000 \\
\hline Post-test & 3.12 & .618 & & \\
\hline
\end{tabular}

As shown in Table 4, there is a significant difference $(\mathrm{p}=0.000)$ between the pre-test and the post-test, which indicates that the pupils' performance has increased significantly after the four-month task-based learning. As such, we have evidence to reject the null hypothesis and accept the alternative hypothesis which assumes that the pupils' speaking skills improve significantly after learning through the tasked-based approach under the LINUS program. This study proves that task-based learning improves the speaking ability of primary school pupils significantly. In the taskbased learning approach, students are exposed to various skills on how to handle and share conversations, which in turn, guides them to develop speaking ability efficiently. This exposure is likely to influence the pupils' early speaking proficiency and contribute results in significant performance.

\section{DISCUSSION}

The findings reported in this study demonstrated that pupils under the LINUS program develop speaking abilities significantly through task-based learning. This study further indicates that four-month task-based learning activities under the LINUS program can result in significant improvements in learners' speaking performance. These findings are consistent with the assumption of the social constructivist theory that effective learning takes place when it involves communication, participation, and physical activities (Vygotsky, 1978). The findings of this study also concur with many previous studies on the effectiveness of task-based learning in developing English learners' speaking skills (Dewi et al., 2020; Fang et al., 2021; Nita \& Rozimela, 2019; Omar et al., 2021; Sariannur, 2017). Task-based learning activities are conducted fascinatingly as learners communicate freely with instructors and peers.

The application of task-based learning supports pupils' speaking skills by underscoring the principle of cooperation and communication using the target language (Zaki \& Yunus, 2014). Besides, the principles of constructivism that are embedded in the task-based learning activities help pupils to acquire essential skills such as communication, cooperation, creativity, and critical thinking. Some activities that could further enhance pupils' speaking ability include watching English videos, listening to English songs, and practicing English inside and outside of the classroom (Mercado, 2017). The task-based instruction also provides learners with chances to interact, share, and construct knowledge, which allows for two-way communication in the learning process. These activities could enhance learners' speaking proficiency (Erten \& Altay, 2009). Erten and Altay (2009) stated that "task-based activities are likely to involve more frequent use of collaborative behaviors than topic-based activities, and can thus, be more conducive to creating a collaborative learning experience" (p. 126).

To sum up, this study has proven that the application of task-based activities could enhance pupils' speaking skills under the LINUS program. In essence, this evidence could contribute to achieving the objectives of the LINUS program as set forth by the Malaysian Government's Education Blueprint 2015-2025. One of the major contributions of this study lies in its specific focus on primary school pupils' speaking ability under the LINUS program. Speaking ability represents one of the fundamental language skills, particularly among primary school pupils. This is because early proficiency is likely to influence learners' language skills in general, and specifically, help them to attain a high level of speaking achievements.

\section{DISCUSSION}

This study examined the effectiveness of task-based learning among primary school pupils under the LINUS program in Malaysia. According to the findings, task-based learning enhances pupils' English speaking achievement significantly. The task-based learning approach provides learners with chances to interact with peers and teachers to develop self-confidence, which in turn, helps them acquire language skills. It was envisaged that the findings of this study could be useful to English instructors, particularly primary school teachers, by providing valuable insights into the application of task-based learning activities in developing pupils' English speaking proficiency, particularly under the LINUS program. This information could help instructors to readjust their teaching strategies to suit pupils' intellect in developing speaking abilities and effective conversation using the target language.

Additionally, relevant educational authorities may find this study useful in the development of the English language curriculum to further suit the needs of primary school pupils in Malaysia. Considering its effectiveness, as demonstrated in this study, task-based learning components should be integrated into the language curriculum. This study has provided insights into the effectiveness of task-based learning in developing speaking abilities. However, the study is limited to primary school pupils under the LINUS program. Further research may focus on the application of task-based learning to improve other language skills such as listening, reading, and writing under the LINUS program. These research areas, if investigated methodically, could enrich the task-based learning literature. Likewise, this study can be replicated to incorporate the computer-based learning approach which is particularly relevant in the age of 
communication technology.

\section{REFERENCES}

[1] Ab Rashid, R., \& Al-Smadi, O. A. (2020). Causes of speaking anxiety among Saudi students: Learners' problematic attitudes and beliefs. Journal of Qualitative Social Sciences, 2. 1, 12-21.

[2] Abugohar, M. A., \& Yunus, K. (2018). Difficulties encountered by Arab students in pronouncing English correctly. International Journal of Education and Literacy Studies, 6. 4, 93-100.doi: 10.7575/aiac.ijels.v.6n.4p.93

[3] Ahmed, R. Z., \& Bidin, S. J. B. (2016). The effect of task-based language teaching on writing skills of EFL learners in Malaysia. Open Journal of Modern Linguistics, 6. 3, 207-219.doi: 10.4236/ojml.2016.63022

[4] Al-Tamimi, N. O. Abdullah, N. K., Bin-Hady, W. R. (2020). Teaching speaking skill to EFL college students through taskbased approach: Problems and improvement. British Journal of English Linguistics, 8. 2, 113-130.

[5] Annamalai, N. (2019). The use of web 2.0 technology tools and beyond in enhancing task-based language learning: A case study. The English Teacher, 48. 1, 29-44.

[6] Arsal, Z. (2017). The impact of inquiry-based learning on the critical thinking dispositions of pre-service science teachers. International Journal of Science Education, 39. 10,1326-1338. doi: 10.1080/09500693.2017.1329564

[7] Azlan, N. A. B., Zakaria, S. B., \& Yunus, M. M. (2019). Integrative task-based learning: Developing speaking skills and increase motivation via Instagram. International Journal of Academic Research in Business and Social Sciences, 9. 1, 620-636.

[8] Azmi, M. N. L., Hassan, I., Ali, E. M. T., Abdullah, A. T. H., Anas, M., \& Suhaimi, N. I. (2020). Teachers' Perceptions of Islamic Self-Identity Formation through Language Learning among Students in Selected Religious Secondary Schools. International Journal of Society, Culture, and Language, 8. 1, 83-91.

[9] Bakhtiary, M. R., Rezvani, E., \& Namaziandost, E. (2021). Effects of strategic and unpressured within-task planning on Iranian intermediate EFL learners' oral production. Journal of Nusantara Studies (JONUS), 6. 2, 97-115.doi: 10.24200/jonus.vol6iss2pp97-115

[10] Bokhari, R., Md Rashid, S., \& Chan S. H. (2015). Teachers' perception on the implementation of the Literacy, Numeracy, and Screening (LINUS LBI 2.0) program. Malaysian Journal of ELT Research, 11. 1, 108-121.

[11] Chew, F. P. (2018). Evaluation of the Literacy and Numeracy Screening Program in three types of national primary schools in Malaysia. Journal of Contemporary Educational Research, 2. 5, 27-35.doi: 10.26689/jcer.v2i5.432

[12] Creswell, J. W. (2007). Qualitative inquiry and research design: Choosing among five approaches (2nd ed.). Thousand Oaks, CA: Sage.

[13] Dewi, A. K., Ratminingsih, N. M., \& Santosa, M. H. (2020). Mobile-Assisted task-based language learning, writing competency, and motivation. Jurnal Pendidikan Indonesia, 9. 1, 119-130.doi: 10.23887/jpi-undiksha.v9i1.23164

[14] Erten, I. \& Altay, M. (2009). The effects of task-based group activities on students' collaborative behaviors in EFL speaking classes, Journal of Theory \& Practice in Education, 5. 1, 33-52.

[15] Fang, W. C., Yeh, H. C., Luo, B. R., \& Chen, N. S. (2021). Effects of mobile-supported task-based language teaching on EFL students' linguistic achievement and conversational interaction. ReCALL, 33. 1, 71-87.doi: 10.1017/S0958344020000208

[16] Ghazali, N., Omar, M. C., \& Saputra, J. (2021). A study of English literacy implementation challenges among primary school teachers in Kelantan, Malaysia. http://www.ieomsociety.org/singapore2021/papers/562.pdf (Accessed 22/06/2021).

[17] Hadzir, N., Alias, A. M., Kamaruzaman, A. L., \& Yusof, H. M. (2016). Teachers' perceptions on Literacy, Numeracy, and Screening (LINUS 2.0) assessment features based on Year 1 students' performance. Research Journal of English Language and Literature (RJELAL). 4. 1, 2321-3108.

[18] Harmer, J. (2007). The practice of English language teaching. England: Pearson Education Limited.

[19] Hasan, A. A. A. (2014). The effect of using task-based learning in teaching English on the oral performance of secondary school students. International Interdisciplinary Journal of Education, 3. 2, 1-15.

[20] Leong L., Ahmadi S. M. (2017). An analysis of factors influencing learners' English speaking skills. International Journal of Research in English Education, 2. 1, 34-41.

[21] Luyee, E. O., Roselan, F. I., Anwardeen, N. H., \& Mustapa, F. H. M. (2018). Suitability of the literacy and numeracy screening (LINUS) 2.0 program in assessing children's early literacy. MOJES: Malaysian Online Journal of Educational Sciences, 3. 2, 36-44.

[22] Mechraoui, K. K., Mechraoui, A., \& Quadri, K. M. (2014). The effect of task-based language teaching on learner autonomy: A case of pre-university students at the International Islamic University Malaysia. International Journal of Humanities and Management Sciences, 2. 1, 6-10.

[23] Mercado, E. M. (2017). A task-based speaking course for Ninth Grade students of the Institución Educativa Inobasol De Soledad. Master's thesis, Universidad Del Norte.

[24] Ministry of Education. (2014). LINUS 2.0 Literasi Bahasa Inggeris (LBI) teacher's module Book 1. Kuala Lumpur: Bahagian Pembangunan Kurikulum Kementerian Pendidikan Malaysia.

[25] Muhamad, S. N., Latiff Azmi, M. N., \& Hassan, I. (2020). Reading interest and its relationship with reading performance: A study of English as second language learners in Malaysia. Humanities \& Social Sciences Reviews, 7. 6, 1154-1161.doi: 10.18510/hssr.2019.76165

[26] Murad, T. M. (2009). The effect of task-based language teaching on developing speaking skills among the Palestinian secondary EFL students in Israel and their attitudes towards English. PhD dissertation, Yarmouk University.

[27] Musazay, A., Khalid, M. (2017). Teachers' perspectives on task-based language teaching A case study at International Islamic University Malaysia. IUM Journal of Educational Studies, 5. 1, 62-75.

[28] Musliman, R., Ariffin, S. R., \& Din, R. (2013). Assessing students' spatial intelligence for literacy and numeracy skills. Procedia - Social and Behavioural Sciences, 90. 1, 695-701.

[29] Nita, A., \& Rozimela, Y. (2019). The influence of task-based language teaching on speaking skills of EFL students with intrinsic motivation. International Journal of Literature and Arts, 7. 6, 179-184. doi: 10.11648/j.ijla.20190706.18 
[30] Omar, Z., Jamaludin, N., \& Arshad, M. (2021). Effects of task-based language teaching on speaking skills. Malaysian Journal of Education, 46. 1, 49-58.

[31] Palys, T. (2008). Purposive sampling. In L. Given (Ed.). The Sage Encyclopaedia of Qualitative Research Methods. Los Angeles: SAGE Publications.

[32] Pashaie, S., \& Khalaji, H. (2014). The effect of task outcome on speaking improvement of pre-intermediate high school students in Malayer. International Journal of Educational Investigations, 1. 2, 43-53.

[33] Powell, K.C., Kalina, C.J. (2009). Cognitive and social constructivism: Developing tools for an effective classroom. Education, 130. 2, 241-250.

[34] Sani, N. B., \& Idris, A. R. (2017). Identifying the challenges encountered by teachers in dealing with indigenous students. MOJEM: Malaysian Online Journal of Educational Management, 1. 3, 48-63.

[35] Sariannur. (2017). The effect of using Task-Based Learning ( TBL ) method on students' achievement in reading comprehension at Madrasah Aliyah Negeri 1 Natal. PhD dissertation, Universitas Islam Negeri Sumatera Utara.

[36] Sholeh, M. B. (2020). Implementation of task-based learning in teaching English in Indonesia: Benefits and problems. Language Circle: Journal of Language and Literature, 15. 1, 1-9.doi: 10.15294/lc.v15i1.26004

[37] Stake, R. (1995). The art of case study research. London: Sage.

[38] Tew, E.W. K. (2015). Towards an understanding of critical thinking. http://eprints.uwe.ac.uk/25402 (Accessed 13/07/2021.

[39] Thanghun, K. (2012). Using task-based learning to develop the English speaking ability of Pratham 6 students at Piboonprachasan School. http://ir.swu.ac.th/xmlui/bitstream/handle/123456789/4172/Kesda_T.pdf? sequence $=1$ (Accessed 04/04/2021)

[40] Tuan, N. H., \& Mai, T. N. (2015). Factors affecting students' speaking performance at LE Thanh Hien High School. Asian Journal of Educational Research, 3. 2, 8-23.

[41] Vygotsky, L. S. (1978). The mind in society: The development of higher psychological processes. Cambridge, MA: Harvard University Press.

[42] Wen, C. H., Ying, L. C., \& Azlan, M. A. K. (2018). The influence of task-based language teaching and audio-lingual teaching approach on Mandarin language learning outcomes. International Journal of Social Sciences, 4. 3, 123-141

[43] Yin, R. K. (2003). Case study research design and methods: Washington DC: Sage Publications.

[44] Zaki, A. A., \& Yunus, M. M. (2014). Strategies used by local ESL teachers in Malaysia to create a constructivist classroom. http://dspace.unimap.edu.my (Accessed 19/01/2021.

[45] Zaki, M. H. S., Yunus, M. M., \& Hashim, H. (2017). The use of audiovisual aids in developing pupils' speaking skills: Malaysian context. Asian Social Science Journal, 4. 1, 165-172.

Isyaku H. is a Postdoctoral Researcher at the Center for Modern Languages and Communication, Faculty of Languages and Communication, Universiti Sultan Zainal Abidin (UniSZA), Terengganu, Malaysia. His areas of research interest include media linguistics, literary analysis, and language studies.

Izatil A. M. Zamzam is a Postgraduate Student at the Center for English Language Studies, Faculty of Languages and Communication, Universiti Sultan Zainal Abidin (UniSZA), Terengganu, Malaysia. She researches second language acquisition, focusing on the development of speaking skills via task-based learning.

Mohd Nazri L. Azmi is an Associate Professor of English at the Center for English Language Studies, Faculty of Languages and Communication, Universiti Sultan Zainal Abidin (UniSZA), Terengganu, Malaysia. His areas of research interest include literacy and comparative literature, second language acquisition, and language studies.

Ahmad T. H. Abdullah is a Senior Lecturer at the Center for English Language Studies, Faculty of Languages and Communication, Universiti Sultan Zainal Abidin (UniSZA), Terengganu, Malaysia. His areas of research interest include public speaking, language studies, and second language acquisition. 